\title{
NONLINEAR MODELS TO PREDICT NITROGEN MINERALIZATION IN AN OXISOL
}

\author{
Janser Moura Pereira ${ }^{1}$; Joel Augusto Muniz ${ }^{2 *}$; Carlos Alberto Silva ${ }^{3}$ \\ ${ }^{1}$ UFLA - Pós-Graduando em Estatística e Experimentação Agropecuária. \\ ${ }_{3}^{2} U F L A$ - Depto. de Ciências Exatas, C.P. 37 - 37200-000 - Lavras, MG - Brasil. \\ ${ }^{3}$ UFLA - Depto. de Ciência do Solo. \\ *Corresponding author <joamuniz@ufla.br>
}

\begin{abstract}
This work was carried out to evaluate the statistical properties of eight nonlinear models used to predict nitrogen mineralization in soils of the Southern Minas Gerais State, Brazil. The parameter estimations for nonlinear models with and without structure of autoregressive errors was made by the least squares method. First, a structure of second order autoregressive errors, AR(2) was considered for all nonlinear models and then the significance of the autocorrelation parameters was verified. Among the models, the Juma presented an autocorrelation of second order, and the model of Broadbent presented one of first order. In summary, these models presented significant autocorrelation parameters. To estimate the parameters of nonlinear models, the SAS procedure MODEL was used (SAS). The comparison of the models was made by measuring the fitted parameters: adjusted R-square, mean square error and mean predicted error. The Juma model with AR(2) best fitted for nitrogen mineralization without liming, followed by Cabrera, Stanford \& Smith without autoregressive errors, for both with and without soil acidity correction.
\end{abstract}

Key words: autoregressive, estimators properties, mineralized nitrogen, variance, covariance matrices

\section{MODELOS NÃO LINEARES PARA PREDIZER A MINERALIZAÇÃo DE NITOGÊNIO NUM LATOSSOLO}

\begin{abstract}
RESUMO: Este trabalho teve por objetivo avaliar o grau do ajuste de oito modelos não lineares apresentados na literatura, utilizados para descrever a mineralização do nitrogênio em latossolo do sul de Minas Gerais incubado durante 28 semanas. A estimação dos parâmetros para os modelos de regressão não linear sem e com estrutura de erros autorregressivos foi feita pelo método de mínimos quadrados. A princípio, considerouse para todos os modelos não lineares uma estrutura de erros autorregressivos de segunda ordem, $\mathrm{AR}(2) \mathrm{e}, \mathrm{em}$ seguida, verificou-se a significância dos parâmetros de autocorrelação. Apenas o modelo de Juma apresentou autocorrelação de segunda ordem, e o modelo de Broadbent apresentou autocorrelação de primeira ordem, ou seja, apenas estes modelos apresentaram parâmetros de autocorrelação significativos. Para estimação dos parâmetros dos modelos não lineares, utilizou-se o procedimento MODEL ( $\mathrm{SAS}^{\circledR}$ ). A comparação dos modelos foi feito por meio de critérios da qualidade do ajuste (coeficiente de determinação ajustado, quadrado médio do resíduo e erro de predição médio). O modelo de melhor ajuste foi o de Juma com AR(2), para a mineralização de N sem calagem, seguido pelos modelos de Cabrera, Stanford \& Smith sem estrutura de erros autorregressivos, tanto para os dados com, quanto para aqueles obtidos sem a correção da acidez do solo.

Palavras-chave: autorregressivo, propriedades dos estimadores, nitrogênio mineralizado, matriz de variância, covariância
\end{abstract}

\section{INTRODUCTION}

Nitrogen is the most required nutrient by crops. The high cost and the large need of plants for nitrogen make $\mathrm{N}$ the most limiting nutrient for food production in the world. Nitrogen is found in soils predominantly in the organic form as a component of different soil organic compounds. Compared to other nutrients, nitrogen undergoes several transformations in soil which makes $\mathrm{N}$ availability to plants difficult to be evaluated. Mineralization is one of the $\mathrm{N}$ transformation processes in soils and it consists of the conversion of organic $\mathrm{N}$ into mineral $\mathrm{N}$ (ammonia), which under acid conditions is converted rapidly into ammonium. This process increases in part the soil availability of $\mathrm{N}$ to crops since plants are not capable of absorbing $\mathrm{N}$ in organic forms. The mineralization process is influenced by a number of factors, such as: soil type, organic matter content, total $\mathrm{N}, \mathrm{C} / \mathrm{N}$ ratio, $\mathrm{pH}$, temperature, soil moisture, drying, level of soil acidity, supply of inorganic nutrients and soil/plant interactions (Haynes, 1986). Among these factors, soil acidity exerts an important role in conditioning the nitrogen mineralization rates since soil acidity correction generally increases the amounts of mineralized nitrogen (Nyborg et al., 1988; Silva et al., 1994). 
The evaluation of $\mathrm{N}$ availability may be achieved by means of short term biologic methods using soil sample incubation in laboratory as a basis for making $\mathrm{N}$ fertilizers recommendations for crops (Foth \& Ellis, 1988). The incubation process consists of conditioning soils providing to the organisms associated to organic $\mathrm{N}$ conversion to ammonium the optimum conditions to obtain the maximum mineralization rates. Under controlled conditions, it is necessary to add water, nutrients, limestone and other inputs that limit the activity of mineralizing organisms in order to evaluate the soil $\mathrm{N}$ mineralization potential as a function of time.

Mineralization of organic matter is higher during initial incubation periods due to the consumption by soil organisms of the most easily decomposable organic compounds (Gupta \& Reuszer, 1967; Chew et al., 1976), and on account of the factors which may accelerate organic matter decomposition such as soil tillage processes, drying, and grinding (Black, 1968).

Using empirical models it is possible to report and predict the relationships among events taking place in nature by fitting mathematical equations to experimental data (Camargo et al., 2002). To evaluate nitrogen mineralization dynamics in the soil, it is important to know which model best describes how this phenomenon is related to time. $\mathrm{N}$ mineralization in soil, according to Stanford \& Smith (1972), may be described by a simple exponential model, which relates the mineralized $\mathrm{N}$ from a single potentially mineralizable $\mathrm{N}$ compartment to the incubation time, at a rate proportional to its concentration in soil. In other studies (Molina et al., 1980; Inobushi et al., 1985), the existence of two $\mathrm{N}$ compartments in the soil is taken into account, one with more and other with less mineralization potential, though Camargo et al., (2002) have rejected the hypothesis of the existence of more than one $\mathrm{N}$ compartment in the soil, susceptible to mineralization.

In fertilization programs, most of the $\mathrm{N}$ required by crops is supplied by mineral fertilizers. When high amounts of $\mathrm{N}$ are added to soil, a great concern exists in relation to water and atmosphere pollution due to the inefficient use of nitrogen fertilizers by plants which demands new alternatives that make possible the substitution of all or part of those inputs (Scivittaro et al., 2000) and the better use of nitrogen supplied by soil through the mineralization process.

The prediction, by means of mathematical models, of amounts of mineralized $\mathrm{N}$ over time, in soils under different management systems assumes great importance relative to the following aspects: 1) allows the evaluation of soil capacity to supply $\mathrm{N}$ to plants; 2 ) makes the evaluation of mineral- $\mathrm{N}$ availability (nitrate + ammonia) possible in soils under different management systems; 3) allows the determination of the best soil management practices in order to increase the $\mathrm{N}$ use efficiency in the soil-plant system; 4) predicts the possibility of soil contamination and quantificates nitrate fluxes to the water reservoirs; 5) furnishes the basis for defining correctly the $\mathrm{N}$ rates for different crops.

Based on Camargo et al. (2002), the present work proposes the matrix of variance and covariance parameters of these models (Draper \& Smith, 1998), considering also autoregressive errors. To evaluate the degree of fitting of experimental data related to nitrogen mineralization in the Southern Minas Gerais State Oxisol incubated during 28 weeks in laboratory conditions, eight nonlinear models were chosen.

\section{MATERIAL AND METHODS}

Eight nonlinear models were evaluated by fitting experimental data associated with $\mathrm{N}$ mineralization in a Minas Gerais, (Brazil) Oxisol under the effect or not of liming. These data were obtained by Silva et al. (1994) and are related to the accumulated amounts of mineralized $\mathrm{N}$ during eleven incubation times $(1,2,3,4,6,8$, $10,12,14,21$ and 28 weeks). Soil acidity correction was made in order to elevate the soil base saturation to $60 \%$ and the $\mathrm{pH}$ to values in the range of 6.0-6.2. Mineral $\mathrm{N}$ extraction (nitrate + ammonium) formed during incubation was performed by periodic washing of the soil with a $0.01 \mathrm{~mol} \mathrm{~L}^{-1} \mathrm{CaCl}_{2}$ solution. The quantification of mineralized $\mathrm{N}$ was performed in a steam draft distiller, with $\mathrm{N}$-ammonium being quantified after addition of $\mathrm{MgO}$ in the $\mathrm{CaCl}_{2}$ extract and nitrate after use of Devarda alloy in the remaining extract. Soil samples were incubated under laboratory conditions with air temperatures ranging between 21 and $28^{\circ} \mathrm{C}$. The experimental design was completely randomized with three replicates of $50 \mathrm{~g}$ of soil, with soil acidity corrected or not, mixed to $50 \mathrm{~g}$ of medium sand and incubated in funnels during 0 to 28 weeks. The mineralized amounts of $\mathrm{N}$ were accumulated in time (weeks). The nonlinear empirical models to predict $\mathrm{N}$ mineralization in relation to time (weeks) are presented in Table 1.

The description of the terms (parameters) in these models is as follows:

$N_{m}$ is the mineralized nitrogen at time $\mathrm{t} ; t$ is the incubation time (weeks); $N_{0}$ is the potentially mineralizable Nitrogen; $h, k, k_{0}, k_{1}, k_{2}, k_{q}$ e $k_{s}$ are mineralization rates; $S$ is the least stable fraction of organic nitrogen; $(1-S)$ is the resistant fraction of organic nitrogen; $N_{1}$, $N_{0 . q}$ are the easily mineralizable $\mathrm{N} ; N_{2}, N_{0 s}$ are the hardly mineralizable N; $A$ and $b$ are constants; $\varepsilon$ a vector of errors with normal distributions with mean zero and variance $\sigma^{2}$. This structure of the errors was considered for the models with no autocorrelation in the residuals.

For models which have residual autocorrelations a stationary autoregressive process of first order AR(1) was considered:

$$
u_{t}=\phi u_{t-1}+\varepsilon_{t}, \quad-1 \leq \phi \leq 1,
$$


in which $\phi$ is the autocorrelation parameter and $\varepsilon_{t}$, the white noise (Hoffmann \& Vieira, 1998).

If necessary a second order autoregressive process, AR(2), was considered (Morettin \& Toloi, 2004):

$$
u_{t}=\phi_{1} u_{t-1}+\phi_{2} u_{t-2}+\varepsilon_{t} .
$$

here $\phi_{1}$ and $\phi_{2}$ are autocorrelation parameters and $\varepsilon_{t}$ is the white noise. The process is stationary if $\phi_{1}+\phi_{2}<1, \phi_{2}-\phi_{1}<1$ and $-1<\phi_{2}<1$.

In studies using regression models, it is assumed that errors are independent. Generally the problem of autocorrelated errors appears with longitudinal data, in which the error of observation relative to one period is correlated with the error in the previous observation (Hoffman \& Vieira, 1998). However, in the case of using nonlinear models for the description of the index of soil nitrogen mineralization, it is important to consider autocorrelation since measures of accumulated nitrogen are taken at several times in the same plot, which make them likely to be correlated.

Simple exponential models consider the existence of only one "pool", where the potentially mineralizable N, $\left(N_{0}\right)$, is decomposed in a rate proportional to its concentration, while the double exponential models consider the existence of two "pools" or compartments. Thus, there are two rates taking place in the process, one relative to the soil organic matter compartment that is more stable (resistant) and the other to the compartment that is less stable.

The hyperbolic model of Juma et al. (1984) provides an estimate of the half life $(\sqrt{t})$ of the nitrogen mineralization (Camargo et al., 2002), while the parabolic model of Broadbent (1986) used by Stanford \& Smith (1972) gives a pre-estimate of the potentially mineralizable nitrogen $\left(N_{0}\right)$.

Estimates of the parameters for the nonlinear models with and without AR(1) and AR(2) error structures were obtained only for the models that have shown autocorrelation in residuals. The least squares estimation of the parameters was made using the iterative algorithm of Marquardt (1963), implemented in the PROC MODEL $\left(\mathrm{SAS}^{\circledR}, 1999\right)$ statistic software. The nonlinear models were evaluated using the mean square error MSE (Draper \& Smith, 1998), the adjusted coefficient of determination, Adj $R^{2}$, (Draper \& Smith, 1998) and the mean prediction error, MPE, (Mazzini et al., 2005).

\section{RESULTS AND DISCUSSION}

After models were fitted to the experimental results, with and without liming, first considering the models without autoregressive errors, models AR(1) and

Table 1 - Nonlinear models for the mineralization of soil $\mathrm{N}$ related to time (weeks).

\begin{tabular}{lll}
\hline Model & \multicolumn{1}{c}{ Equation } & \multicolumn{1}{c}{ Reference } \\
\hline a) Simple exponential & $N_{m}=N_{0}[1-\exp (-k t)]+\varepsilon$ & Stanford \& Smith (1972) \\
b) Simple Exponential & $N_{m}=N_{0}\left[1-\exp \left(-k t^{b}\right)\right]+\varepsilon$ & Marion et al. (1981) \\
c) Simple Exponential & $N_{m}=N_{1}+N_{2}-\left[N_{2} \exp \left(-k_{2} t\right)\right]+\varepsilon$ & Jones (1984) \\
d) Simple Exponential & $N_{m}=N_{1}\left[1-\exp \left(-k_{1} t\right)\right]+k_{0} t+\varepsilon$ & Cabrera (1993) \\
e) Double Exponential & $N_{m}=N_{0} \mathrm{~S}[1-\exp (-h t)]+N_{0}(1-\mathrm{S})[1-\exp (-k t)]+\varepsilon$ & Molina et al. (1980) \\
f) Double Exponential & $N_{m}=N_{0 q}\left[1-\exp \left(-k_{q} t\right)\right]+N_{0 s}\left[1-\exp \left(-k_{s} t\right)\right]+\varepsilon$ & Inobushi et al. (1985) \\
g) Hyperbolic & $N_{m}=\left(N_{0} t\right) /(\sqrt{t}+t)+\varepsilon$ & Juma et al. (1984) \\
h) Parabolic & $N_{m}=A t^{b}+\varepsilon$ & Broadbent (1986) \\
\hline
\end{tabular}

Table 2 - Nonlinear model fitting with and without structure of autoregressive errors, with and without liming.

\begin{tabular}{|c|c|c|c|c|c|c|}
\hline \multirow{3}{*}{ Model } & \multicolumn{6}{|c|}{ Without autocorrelation } \\
\hline & \multicolumn{3}{|c|}{ With liming } & \multicolumn{3}{|c|}{ Without liming } \\
\hline & $M S E^{(1)}$ & $A d j \mathrm{R}^{2}(2)$ & $M P E^{(3)}$ & $M S E$ & Adj $\mathrm{R}^{2}$ & $M P E$ \\
\hline Stanford \& Smith & 38.4463 & 0.9814 & 1.3830 & 38.4870 & 0.9826 & 0.5941 \\
\hline Marion & 43.0722 & 0.9791 & 1.7016 & 40.0188 & 0.9819 & 2.2012 \\
\hline Jones & 41.4207 & 0.9799 & -0.1028 & 43.2826 & 0.9804 & 0.4722 \\
\hline Cabrera & 34.6192 & 0.9832 & 2.5683 & 27.4255 & 0.9876 & 2.4072 \\
\hline Molina & 39.5588 & 0.9808 & 2.5496 & --- & --- & --- \\
\hline Inobushi & 39.5588 & 0.9808 & 2.5456 & --- & --- & -- \\
\hline Juma & 70.6864 & 0.9657 & -1.1091 & 74.4128 & 0.9663 & -1.5212 \\
\hline \multirow[t]{2}{*}{ Broadbent } & 234.3990 & 0.8863 & -6.3807 & 238.2822 & 0.8922 & -7.7756 \\
\hline & \multicolumn{6}{|c|}{ With autocorrelation } \\
\hline Juma com AR(2) & -- & -- & --- & 17.7257 & 0.9920 & 0.9920 \\
\hline Broadbent com AR(1) & 142.1561 & 0.9311 & 0.9311 & 127.1626 & 0.9425 & 0.9425 \\
\hline
\end{tabular}

${ }^{1} M S E$ Mean Square Error; ${ }^{2}$ Adj $R^{2}$ : Adjusted coefficient of determination; ${ }^{3} M P E$ : Mean Predicted Error. 
$\mathrm{AR}(2)$ for residuals were fitted, when necessary. The process verified whether a model contains autocorrelated errors, i.e., it analyzed the significance of the respective autocorrelation parameter.

Table 2 summarizes the analyses with and without autoregressive errors. Cabrera's and Stanford \& Smith's models presented the lowest values for the MSE for data with and without liming. In Juma's AR(2) and Broadbent's AR(1) models, with and without liming, there was a decrease in the MSE.

Values of $A d j R^{2}$ for the models without autoregressive residuals, except for Juma and Broadbent, were superior to 0.97 . This denotes a good fit. The allowance of the autocorrelation in residuals provided an increase in $\operatorname{Adj} R^{2}$ for Juma's model with AR(2), without liming. It fitted well presenting an $A d j R^{2}$ higher than 0.99 . Broadbent's model with AR(1) errors provided an increase in, but lower than 0.95, this is shown in Figure 1 (the two last plots (h)).

Accordingly to the mean predicted error (MPE) for the models without autoregressive errors (Table 2), Jones' model, followed by Stanford \& Smith's for the cultivation situation without liming, presented the best fits, while Juma and Broadbent's overestimated (negative signal) the observed values. For cultivation with liming, Jones' model presented the best fit. Cabrera, Molina, Inobushi, Marion and Stanford \& Smith underestimated (positive signal) the observed values and the models of

Table 3 - Parameters estimates (Est) lower confidence interval limits (LL), upper limits (UL) for models with and without structure of autoregressive errors, with and without liming.

\begin{tabular}{|c|c|c|c|c|c|c|c|}
\hline \multirow{3}{*}{ Model } & \multirow[b]{3}{*}{ Par. ${ }^{(1)}$} & \multicolumn{6}{|c|}{ Without autocorrelation } \\
\hline & & \multicolumn{3}{|c|}{ With liming } & \multicolumn{3}{|c|}{ Without liming } \\
\hline & & Est & LL & UL & Est & LL & UL \\
\hline \multirow[t]{2}{*}{ Stanford \& Smith } & $N_{0}$ & 158.29 & 147.85 & 168.72 & 160.48 & 148.90 & 172.07 \\
\hline & $k$ & 0.16 & 0.13 & 0.19 & 0.14 & 0.11 & 0.17 \\
\hline \multirow[t]{3}{*}{ Marion } & $N_{0}$ & 157.65 & 143.41 & 171.88 & 157.47 & 143.58 & 171.36 \\
\hline & $k$ & 0.16 & 0.10 & 0.21 & 0.13 & 0.08 & 0.17 \\
\hline & $b$ & 1.01 & 0.79 & 1.23 & 1.07 & 0.85 & 1.29 \\
\hline \multirow[t]{3}{*}{ Jones } & $N_{1}$ & 4.28 & -12.87 & 21.45 & 0.36 & -16.51 & 17.25 \\
\hline & $N_{2}$ & 155.17 & 138.81 & 171.52 & 160.23 & 143.72 & 176.74 \\
\hline & $k_{2}$ & 0.15 & 0.11 & 0.20 & 0.14 & 0.10 & 0.10 \\
\hline \multirow[t]{3}{*}{ Cabrera } & $N_{1}$ & 203.88 & 106.02 & 301.75 & 256.76 & 85.74 & 427.78 \\
\hline & $k_{1}$ & 0.12 & 0.06 & 0.18 & 0.09 & 0.03 & 0.14 \\
\hline & $k_{0}$ & -1.67 & -4.97 & 1.63 & -3.13 & -8.04 & 1.76 \\
\hline \multirow[t]{4}{*}{ Molina } & $N_{0}$ & 323.74 & -18514 & 19161 & --- & --- & --- \\
\hline & $S$ & 0.60 & -32.73 & 33.94 & --- & --- & --- \\
\hline & $h$ & 0.12 & -0.13 & 0.39 & --- & --- & --- \\
\hline & $k$ & -0.009 & -1.12 & 1.10 & --- & --- & --- \\
\hline \multirow[t]{4}{*}{ Inobushi } & $N_{0 q}$ & 197.08 & -479.3 & 873.5 & --- & --- & --- \\
\hline & $k_{q}$ & 0.12 & -0.13 & 0.39 & --- & --- & --- \\
\hline & $N_{0 s}$ & 128.96 & -18564 & 18822 & --- & --- & --- \\
\hline & $k_{s}$ & -0.009 & -1.12 & 1.10 & --- & --- & --- \\
\hline \multirow[t]{2}{*}{ Juma } & $N_{0}$ & 199.45 & 173.45 & 225.46 & 207.05 & 176.54 & 237.55 \\
\hline & $a$ & 6.17 & 4.00 & 8.33 & 7.36 & 4.64 & 10.07 \\
\hline \multirow[t]{3}{*}{ Broadbent } & $A$ & 44.17 & 29.59 & 58.75 & 39.55 & 25.53 & 53.57 \\
\hline & $b$ & 0.4138 & 0.28 & 0.53 & 0.44 & 0.31 & 0.58 \\
\hline & & \multicolumn{6}{|c|}{ With autocorrelation } \\
\hline \multirow[t]{4}{*}{ Juma with AR(2) } & $N_{0}$ & --- & --- & --- & 224.21 & 187.18 & 261.23 \\
\hline & $a$ & --- & -- & -- & 8.68 & 5.77 & 11.58 \\
\hline & & --- & --- & --- & 1.12 & 0.60 & 1.64 \\
\hline & & --- & --- & --- & -1.21 & -2.08 & -0.34 \\
\hline \multirow[t]{3}{*}{ Broadbent with AR(1) } & $A$ & 33.59 & 6.42 & 60.75 & 28.14 & 2.37 & 53.92 \\
\hline & $b$ & 0.38 & -0.03 & 0.79 & 0.40 & -0.06 & 0.87 \\
\hline & & 0.99 & 0.54 & 1.45 & 1.02 & 0.64 & 1.40 \\
\hline
\end{tabular}

${ }^{1} N_{0}$ : Potentially mineralizable nitrogen; $h, k, k_{0}, k_{1}, k_{2}, k_{q}$ and $k_{s}:$ mineralization rates or constants; $S$ : least stable fraction of organic nitrogen; $N_{1}, N_{0 q}$ : easily mineralizable nitrogen $\mathrm{N} ; N_{2}, N_{0 s}: \mathrm{N}$ hardly mineralizable $\mathrm{N} ; A$ and $b$ : constants; $\phi_{1}$ and $:$ autocorrelation parameters. 

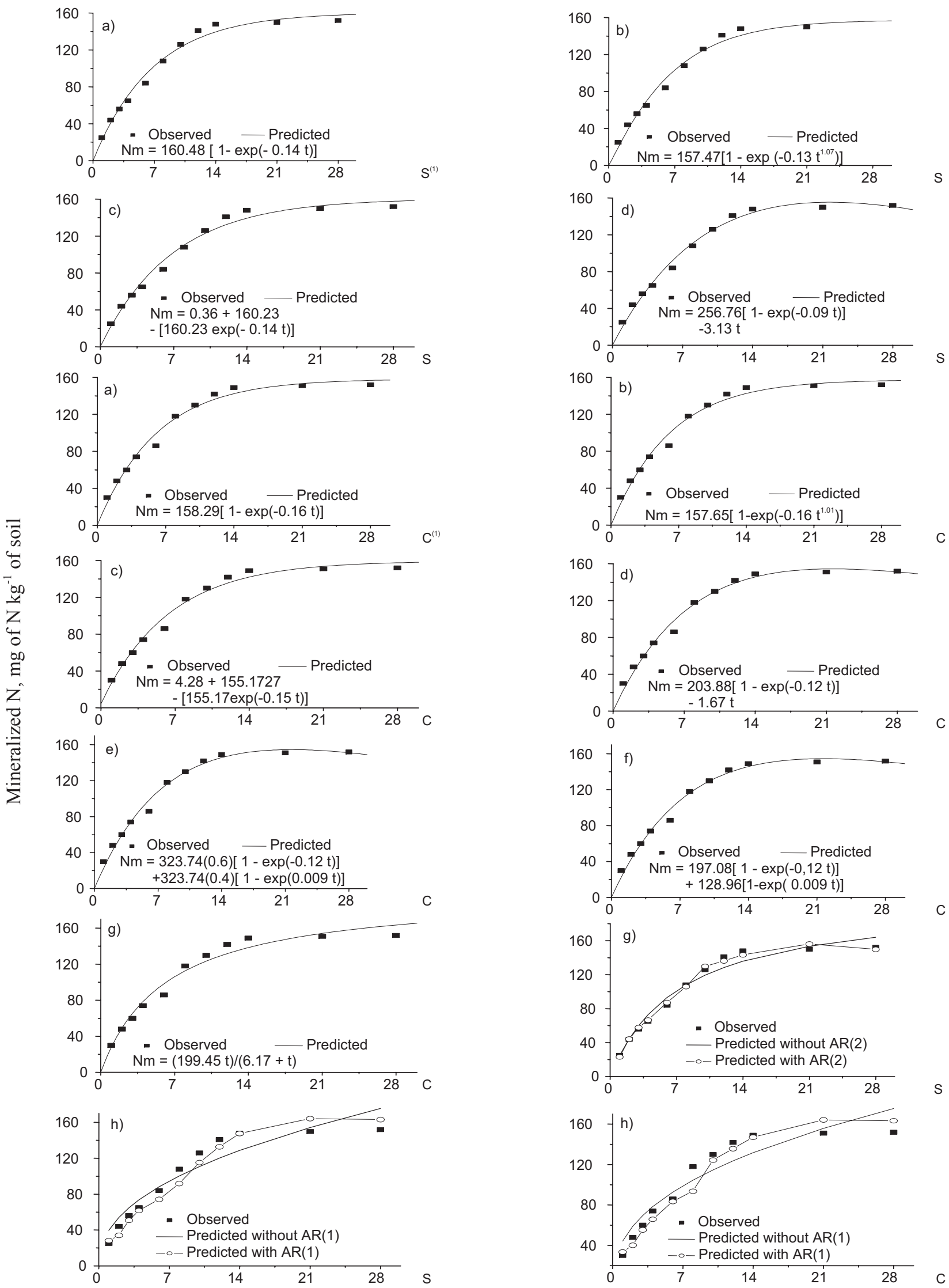

Time (weeks)

Figure 1 - Comparison of models to estimate potentially mineralizable N. Letters in lower case correspondent to the models reported in Table $1 .{ }^{1} \mathrm{C}=$ with liming; $\mathrm{S}=$ without liming. 
Juma and Broadbent overestimated them. The models with autoregressive errors, Juma with $\operatorname{AR}(2)$ and Broadbent with AR(1), underestimated the observed values, i.e., presented positive signal (Table 2).

Jones' model, in both situations (with and without liming) has confidence intervals for the parameter including zero, which means that this parameter is not significant for the data under study (Table 3). Therefore, Jones' model has a structural form equivalent to the Stanford \& Smith's model. Models of Molina and Inobushi also have confidence intervals of parameters containing zero (Table 3). From the standpoint of inference, the parameters could be zero, with no fit. Another aspect of lack of fit is that the intervals of the parameters presented large ranges.

\section{CONCLUSIONS}

Autocorrelated errors were verified only in Juma's model without liming and in Broadbent's model, for soil samples with and without liming. The introduction of autocorrelation improved the fit only for Juma's model with $\operatorname{AR}(2)$ without liming.

The mathematical model that best described the $\mathrm{N}$ mineralization dynamics is that one proposed by Juma with AR(2) in soils sample without soil acidity correction followed by Cabrera's, Stanford \& Smith's models without an autoregressive error structure, for both types of soil.

The model which provided the worst fit was Broadbent's with and without autoregressive error structure, with and without liming.

\section{ACKNOWLEDGEMENTS}

To CNPq for the financial support and scholarships.

\section{REFERENCES}

BLACK, C.A. Soil-plant relationships. New York: John Wiley, 1968. 792p. BROADBENT, F.E. Empirical modeling of soil nitrogen mineralization. Soil Science, v.141, p.208-213, 1986.

CABRERA, M.L. Modeling the flush of nitrogen mineralization caused by drying and rewetting soils. Soil Science Society of America Journal, v.57, p.63-66, 1993.
CAMARGO, F.A. de O.; GIANELLO, C.; TEDESCO, M.J.; RIBOLDI, J.; MEURER, E.J.; BISSANI, C.A. Empirical models to predict soil nitrogen mineralization. Ciência Rural, v.32, p.393-399, 2002.

CHEW, W.Y.; WILLIAMS, C.N.; JOSEPH, K.T.; RAMLI, K. Studies on the availability to plants of soil nitrogen in Malaysian tropical oligotrophic peat. I - Effect of liming and $\mathrm{pH}$. Tropical Agriculture, v.53, p.69-78, 1976.

DRAPER, N.R.; SMITH, H. Applied regression analysis. 3.ed. New York: John Wiley \& Sons, 1998. 706p.

FOTH, H.D.; ELLIS, B.G. Soil fertility. New York; John Wiley \& Sons, 1988. 212p.

GUPTA, U.C.; REUSZER, H.W. Effect of plant species on the aminoacid content and nitrification of soil organic matter. Soil Science, v.104, p.395400, 1967.

HAYNES, R.J. Mineral nitrogen in the plant-soil system. Orlando; Academic Press, 1986. 483 p.

HOFFMANN, R.; VIEIRA, S. Análise de regressão: uma introdução à econometria. 3.ed. São Paulo: HUCITEC, 1998. 379p.

INOBUSHI, K.; WADA, H.; TAKAI, Y. Easily decomposable organic matter in paddy soil. VI. Kinetics of nitrogen mineralization in submerged soils. Journal of Soil Science and Plant Nutrition, v.34, p.563-572, 1985.

JONES, A. Estimation of an active fraction soil nitrogen. Communications in Soil Science and Plant Analysis, v.15, p.23-32, 1984.

JUMA, N.G.; PAUL, E.A.; MARY, B. Kinetic analysis of net mineralization in soil. Soil Science Society of America Journal, v.48, p.465-472, 1984.

MARION, G.M.; KUMMEROW, J.; MILLER, P.C. Predicting nitrogen mineralization in chaparral soils. Soil Science Society of America Journal, v.45, p.956-961, 1981.

MARQUARDT, D.W. An algorithm for minimumsquares estimation of nonlinear parameters. Journal of Society of Applied Mathematic, v.11, p.431-441, 1963.

MAZZINI, A.R. de A.; MUNIZ; J.A.; SILVA, F.F.; AQUINO, L.H. Curva de crescimento de novilhos Hereford: heterocedasticidade e resíduos autorregressivos. Revista Ciência. Rural, v.35, p.422-427, 2005.

MOLINA, J.A.E.; CLAPP, C.E.; LARSON, W.E. Potentially mineralizable nitrogen in soil: the simple exponential model does not apply for the first 12 weeks of incubation. Soil Science Society of American Journal, v.44, p.442-443, 1980.

MORETTIN, P.A.; TOLOI, C.M. de C. Análise de séries temporais. São Paulo: Edgard Blucher, 2004. 534p.

NYBORG, M.; HOYT, P.B.; PENNY, D.C. Ammonification and nitrification of $\mathrm{N}$ in soils at 26 field sites one year after liming. Communications in Soil Science and Plant Analysis, v.19, p.1371-1379, 1988.

SAS INSTITUTE INC. SAS/STAT User's Guide. Version ${ }^{1} 8$ Cary: SAS Institute, 1999.

SCIVITTARO, W.B.; MURAOKA, T.; BIARETTO, A.E.; TRIVELIN, P.C.O. Utilização de nitrogênio de adubos verde e mineral pelo milho. Revista Brasileira de Ciência do Solo, v.24, p.917-926, 2000.

SILVA, C.A.; VALE, F.R.; GUILHERME, L.R. Efeito da calagem na mineralização do nitrogênio em solos de Minas Gerais. Revista Brasileira Ciência do Solo, v.18, p.471-476, 1994.

STANFORD, G.; SMITH, S.J. Nitrogen mineralization potentials of soils. Soil Science of America Journal Proceedings, v.36, p.465-472, 1972.

$\overline{\text { Received May 17, }}, 2004$

Accepted May 19, 2005 